\title{
PTEROGLOSSUS BITORQUATUS, Vig.
}

\author{
Double-collared Araçari.
}

\author{
Specific Character.
}

Pter. mandibulâ inferiore albidâ, fasciâ obliquâ apicali nigrâ ; gulâ guttureque castaneis, hoc subtus nigro marginato; torque pectorali angustâ sulphureâ.

Male. - Head black; sides of the neck and throat chestnut, bordered below by a narrow band of black, to which succeeds a similar one of sulphur-yellow; breast, back of the neck and rump blood-red; abdomen and under tail-coverts sulphur-yellow, the latter tinged with rufous; thighs olive; upper surface, wings and tail dark olive-green; upper mandible greenish yellow; under mandible white, with an oblique mark of black occupying the apical half; both mandibles bounded at the base with a narrow raised belt of white, within which is a thread-like line of white, and on the lower mandible a broader line of black; irides orange-coloured, with a black spot on each side at their inner margin, giving the pupil an horizontal-oval appearance; round the eye a greenish grey ring, the remainder of the orbits beautiful vermilion-carmine red; legs dark greyish green.

Total length, 14 inches; bill, $3 \frac{1}{12} ;$ wing, $4 \frac{7}{8} ;$ tail, $5 \frac{\frac{s}{4}}{4} ;$ tarsi, $1 \frac{1}{4}$

Pteroglossus bitorquatus, Vig. in Zool. Journ., vol. ii. p. 481.-Gould, Mon. of Ramph., pl. 16. -Ib. Sturm's Edit., pl. .-Gray and Mitch. Gen. of Birds, vol. ii. p. 403, Pteroglossus, sp. 5.- Bonap. Consp. Gen. Av., Pteroglossus, sp. 5. nigridens, Wagl.

Tris bird was first characterized as new to science by the late Mr. Vigors, who took the description given by him in the second volume of the "Zoological Journal" above-quoted, from a fine specimen then in his possession, but since transferred to the Museum of the Zoological Society of London; and who states that the specific name bitorquatus was suggested by the two narrow bands, one of yellow, the other of black, which surrounds the chest.

In my former account of this species, I spoke of it as being remarkable for its rarity as well as its beauty and elegance of form,-Mr. Vigors's specimen, one in the collection of the late Earl of Derby, and a third in the Museum at Berlin, being all that had then come under my notice; the bird is, however, no longer rare, numerous specimens having been recently transmitted to this country and to the continent. My own collection contains fine examples procured by Mr. Wallace in the neighbourhood of Para, on the Lower Amazon; and other specimens, also procured by that gentleman in the same locality, form part of the National collection.

The Messrs. Sturm state, in their edition of this work, that the yellow crescent is only found on the breast of the females, and that the male is entirely devoid of it; but I suspect that this is not always the case, as it is very conspicuous in one of the specimens at the British Museum, which I have no doubt is that of a male. To those gentlemen I am also indebted for the following description of the soft parts, the colouring of which was previously unkuown to me:- "Iris orange-coloured, with a black spot on its inner margin on each side, so that the pupil appears horizontal-oval; ring surrounding the eye grey; the rest of the orbits beautiful red, such as would be produced by mixing carmine and vermilion."

The Plate represents this species in a state of excitement at the sight of a snake; it must not, however, be understood that the bird feeds upon these animals; they are merely so represented to show how readily (as mentioned by Prince Maximilian of Wied) they are excited by the sudden appearance of any unwonted object.

The figures represent the two sexes of the natural size. 


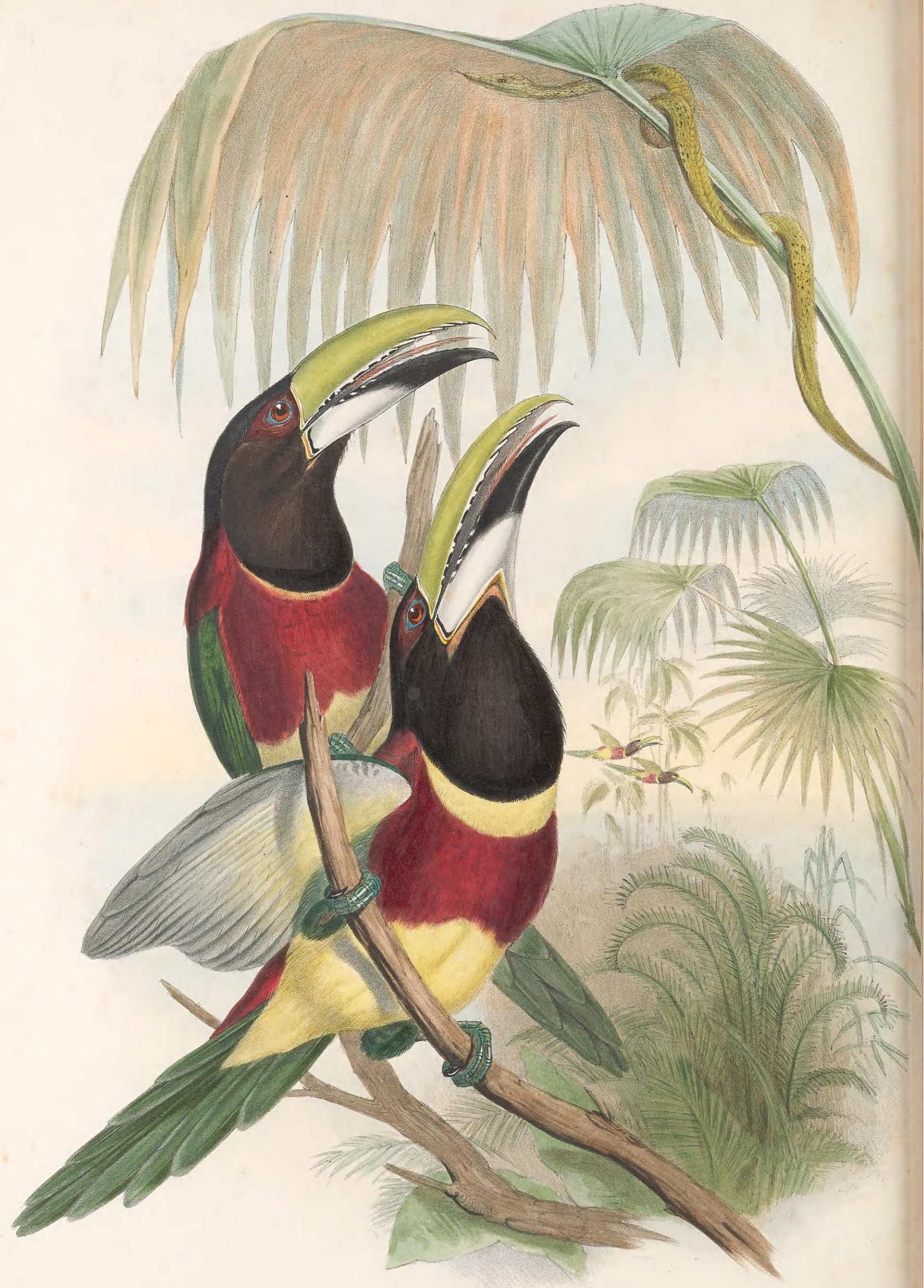

PTERDGLOSSUS BITORQUATUS. Vig. 


\section{$2 \mathrm{BHL}$ Biodiversity Heritage Library}

Gould, John. 1852. "Pteroglossus bitorquatus, Vig., Double-collared Aracari [PI. 26]." A monograph of the Ramphastidae, or family of toucans -. https://doi.org/10.5962/p.322947.

View This Item Online: https://www.biodiversitylibrary.org/item/263319

DOI: https://doi.org/10.5962/p.322947

Permalink: https://www.biodiversitylibrary.org/partpdf/322947.

\section{Holding Institution}

Smithsonian Libraries

\section{Sponsored by}

Biodiversity Heritage Library

\section{Copyright \& Reuse}

Copyright Status: Public domain. The BHL considers that this work is no longer under copyright protection.

This document was created from content at the Biodiversity Heritage Library, the world's largest open access digital library for biodiversity literature and archives. Visit BHL at https://www.biodiversitylibrary.org. 